\title{
Carbon Source and Soil Origin Shape Soil Microbiomes and Tomato Soilborne Pathogen Populations During Anaerobic Soil Disinfestation
}

\author{
Anna L. Testen and Sally A. Miller, ${ }^{\dagger}$ Department of Plant Pathology, The Ohio State University OARDC, Wooster \\ 44691
}

Accepted for publication 20 June 2018.

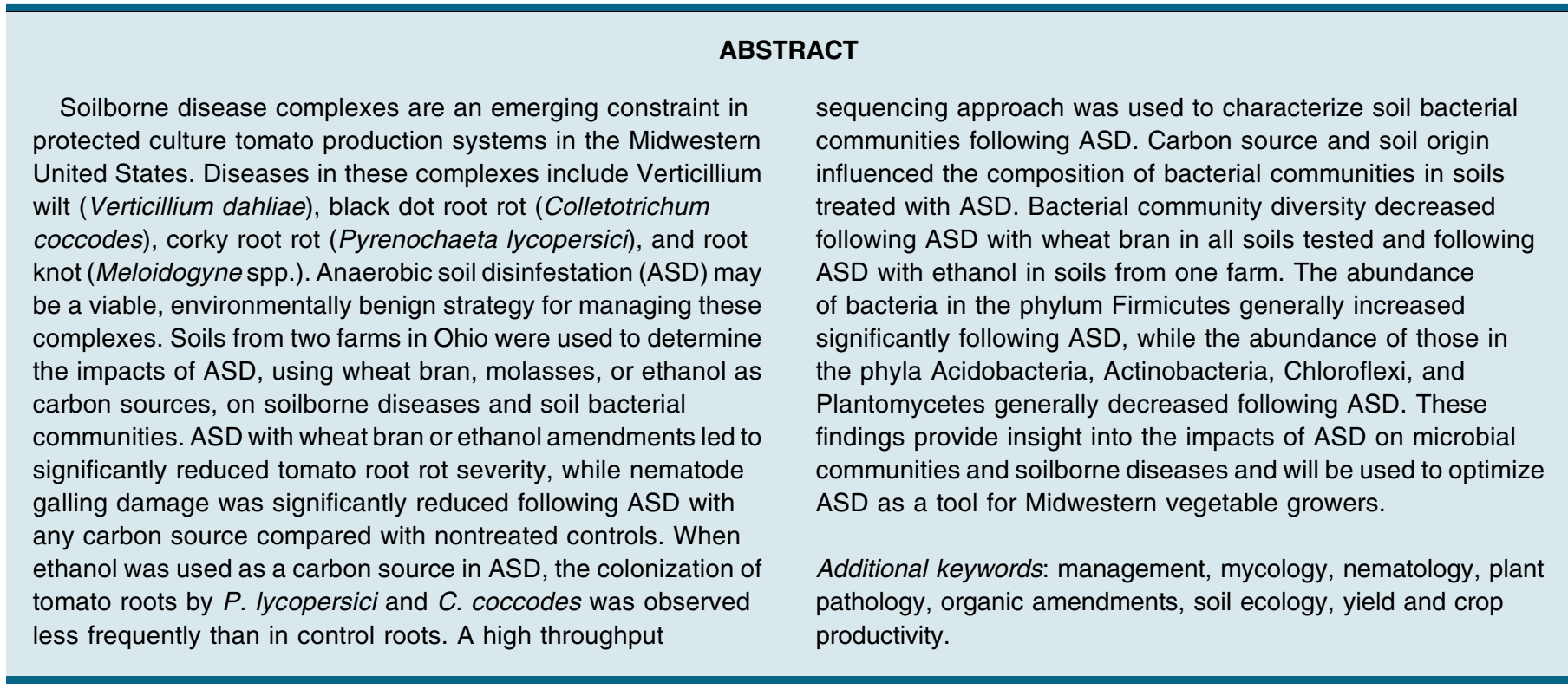

Fresh market tomatoes are a high-value vegetable crop in the Midwestern United States. Production of fresh market tomatoes in protected culture, mainly high tunnels and greenhouses, is increasing as growers seek to capture lucrative markets and mitigate environmental variability. Soilborne disease complexes are an emerging key constraint to the productivity and profitability of protected culture tomato production as growers move toward long-term, continuous production in a single location.

Protected culture systems shelter soilborne pathogens from environmental conditions, likely contributing to buildup and maintenance of various soilborne pathogen populations and the development of soilborne disease complexes. A soilborne disease

${ }^{\dagger}$ Corresponding author: S. A. Miller; E-mail: miller.769@osu.edu

Funding: Salaries and research support were provided by state and federal funds appropriated to the Ohio Agricultural Research and Development Center, The Ohio State University.

(C) 2018 The American Phytopathological Society complex of tomato is present in protected culture systems in Ohio and consists of Verticillium wilt (Verticillium dahliae), black dot root rot (Colletotrichum coccodes), corky root rot (Pyrenochaeta lycopersici) (Vrisman et al. 2017), and root knot (Meloidogyne hapla and $M$. incognita). Individually these pathogens can negatively impact tomato production (Dillard and Cobb 1998; Last and Ebben 1966; López-Pérez et al. 2006; Minuto et al. 2008), but together they severely constrain productivity. Other vascular and root rot pathogens, including Fusarium, Rhizoctonia, and Pythium spp. likely play roles in these complexes as well. Management options are limited for this menagerie of diseases. Grafting preferred tomato scions onto disease-resistant rootstocks (Rivard et al. 2010; Louws et al. 2010) can lessen damage from several of these diseases including Verticillium wilt, corky root rot, and root knot, but grafting does not eliminate pathogen populations from soil. Long-term management of soilborne diseases requires active soil disinfestation.

Soil disinfestation historically relied on chemical-based methods, such as fumigation, and energy-dependent methods, such as steam 
sterilization. Anaerobic soil disinfestation (ASD) is an environmentally benign method of microbial soil rehabilitation in which a carbon source, such as wheat bran or molasses, is incorporated into soil, then the soil is irrigated to saturation and tarped with plastic mulch for several weeks (Blok et al. 2000; Momma et al. 2013). ASD has been applied effectively to a wide range of cropping systems, including fruits (Shennan et al. 2014) and vegetables (Butler et al. 2012a) and reduces populations of fungal (Blok et al. 2000; Mowlick et al. 2014), oomycete (Butler et al. 2012a; SerranoPérez et al. 2017), bacterial (Strauss and Kluepfel 2015; van Overbeek et al. 2013), and nematode pathogens (Butler et al. 2012a; Hewavitharana and Mazzola 2016). ASD has been shown to reduce disease caused by individual members of the tomato soilborne disease complex including V. dahliae (Blok et al. 2000), P. lycopersici by biosolarization (Díaz-Hernández et al. 2017), and Meloidogyne spp. (Butler et al. 2012a; Katase et al. 2009), but no studies have examined the simultaneous impacts of ASD on multiple members of tomato soilborne disease complexes.

ASD is a microbially mediated disease management practice. Soil microbes break down the added carbon source, depleting oxygen and producing toxic compounds, such as organic acids (Momma et al. 2006) and volatile organic compounds (Hewavitharana et al. 2014). During ASD treatment, soil microbial communities change drastically, and following treatment, higher levels of Firmicutes (Lupatini et al. 2017; Mowlick et al. 2013b; Streminska et al. 2014; Wen et al. 2015) are reported most frequently. ASD can reduce diversity of soil microbial communities, but bacterial communities return to diversity levels similar to pre-ASD populations following cropping (Mowlick et al. 2013a; van Agtmaal et al. 2015). The choice of carbon source plays a large role in soil microbial community structure, as carbon sources differentially affect soil microbial populations in ASD (Hewavitharana et al. 2014).

Since it is likely that ASD also affects soilborne pathogens in a carbon source-dependent manner, the tomato soilborne disease complex provides a unique system to examine the impacts of carbon source on a diversity of soilborne pathogens. Wheat bran, molasses, and ethanol, three commonly studied ASD carbon sources, were selected and applied to naturally infested soils at field rates in a bioassay. Since these inputs represent different forms of carbon, we hypothesized that microbial community composition would be altered in a carbon source-dependent manner following ASD and that members of the soilborne disease complex would exhibit differential sensitivity to ASD depending on carbon source. We sought to assess applied and fundamental aspects of ASD through a multifaceted approach that included growth chamber and greenhouse bioassays using naturally infested soils, culture-based approaches, quantitative PCR (qPCR), and high throughput sequencing-based approaches. The objectives of this study were twofold: (i) to assess ASD as a potential tool for management of the tomato soilborne disease complex in Midwestern high tunnel production systems and (ii) to develop a better understanding of differential effects of ASD carbon sources on soil bacterial communities and pathogen populations.

\section{MATERIALS AND METHODS}

Soils. Five soils were collected from two farms in Ohio: a greenhouse in Erie County (northern $\mathrm{OH}$ ) with a history of cropping heirloom tomatoes for eight years and a high tunnel in Highland County (southern $\mathrm{OH}$ ) with a cropping history of 15 consecutive years of tomato production. Soil from at least 15 subsamples (total volume of 57 liters for each soil) was collected at 15-cm depth from three separate greenhouse bays (Bays 12, 21, and 23 for a total of three soil samples) with varied cropping histories from the Erie farm and from each half of the Highland County high tunnel (two soil samples). The texture of the Erie soils was a sandy loam, while the Highland soil texture was a silty clay loam. The Erie greenhouse and the Highland high tunnel were both naturally infested with $V$. dahliae, P. lycopersici, C. coccodes, and Meloidogyne spp. (M. hapla in Erie County and M. incognita in Highland County). The five soils were homogenized in a cement mixer and sieved through $2 \mathrm{~mm}$ mesh sieves prior to use. The cement mixer was cleaned between soil batches by rinsing excess soil from the mixer and running a $20 \%$ solution of commercial bleach (final concentration of $1.2 \%$ sodium hypochlorite) in the mixer followed by another water rinse. Soils were stored at $4^{\circ} \mathrm{C}$ in tightly sealed 19-liter buckets for 3 months until use. Baseline soil physical and chemical properties (Spectrum Analytic Inc., Washington Courthouse, $\mathrm{OH}$ ) are presented in Table 1.

ASD treatment. Subsamples of each of the five soils (630 $\mathrm{g}$ with soil moisture content of $13 \pm 5 \%$ ) were placed in conical pots (Deepots D40H, Steuwe and Sons, Tangent, OR) that contained a base of $90 \mathrm{ml}$ of washed, twice autoclaved pea gravel. Soils were amended with field-applicable rates of one of three carbon sources: wheat bran (20.2 $\mathrm{Mg} \mathrm{ha}^{-1}$, The Mennel Milling Company, Fostoria, $\mathrm{OH}, 2.8 \mathrm{~g}$ of $\mathrm{C}$ per pot [4.4 $\mathrm{mg}$ of $\mathrm{C} \mathrm{g}^{-1}$ of soil], C:N ratio of 17), blackstrap molasses $\left(20.2 \mathrm{Mg} \mathrm{ha}^{-1}\right.$, Golden Barrel blackstrap molasses, Good Food, Inc., Honey Brook, PA, $1.8 \mathrm{~g}$ of $\mathrm{C}$ per pot [2.9 $\mathrm{mg}$ of $\mathrm{C} \mathrm{g}^{-1}$ of soil], $\mathrm{C}: \mathrm{N}$ ratio of 81$)$, or ethanol ( $2 \%$ solution in irrigation water, Acros Chemical, Geel, Belgium, $1.2 \mathrm{~g}$ of $\mathrm{C}$ per pot [1.9 $\mathrm{mg}$ of $\mathrm{C} \mathrm{g}^{-1}$ of soil], $\mathrm{C}: \mathrm{N}$ ratio infinite). Wheat bran was mixed into soils prior to placement in pots, while liquid amendments were poured onto soils in pots. Pots were irrigated with $150 \mathrm{ml}$ of sterile distilled water and allowed to drain for $30 \mathrm{~min}$. Following irrigation, the tops of the pots were covered with black plastic mulch $(1.5-\mathrm{mm}$ super strength embossed mulch, PolyExpert, Quebec, Canada) and sealed with two rubber bands and electrical tape. The bottom of each pot was sealed with plastic mulch and two rubber bands. Nonamended, uncovered pots (aerobic conditions) and nonamended plastic mulch-covered pots (anaerobic conditions) served as controls. Both controls were irrigated as described above, and no supplemental irrigation was applied during the ASD treatment period. Treated and control pots were placed in a growth chamber $\left(30^{\circ} \mathrm{C}\right.$ for $16 \mathrm{~h}, 26^{\circ} \mathrm{C}$ for $8 \mathrm{~h}$ daily) for 3 weeks. Five replications were used per treatment for each of the five soils, and the experiment was conducted twice for a total of 250 experimental units. Individual experiments were blocked by each of the five soils and were placed in a randomized complete block design within the growth chamber.

Reducing conditions in soils were measured using micro-IRIS rods, a modification of IRIS (Indicator of Reduction In Soils) tubes (Rabenhorst 2008; Rabenhorst and Burch 2006). The amount of iron oxide paint removed from these rods serves as a measure of soil reducing conditions. Polyvinyl chloride (PVC) rods $(0.635 \mathrm{~cm}$ diameter, Professional Plastics, Fullerton, CA) were painted with iron oxide paint as described by Rabenhorst (2008). The micro-IRIS rods, $20 \mathrm{~cm}$ in length, were placed $18 \mathrm{~cm}$ into the soil before the soil was covered with mulch. The percentage of paint removed from the rods was evaluated visually once rods were removed from pots (Rabenhorst 2008).

ASD treatment was terminated by removing plastic mulch from the pots after 3 weeks. Soil in each individual pot was used to assess soil reducing conditions via micro-IRIS rods, soil bacterial populations, soil pathogen populations, soil $\mathrm{pH}$, and later in a greenhouse bioassay to determine ASD impacts on plant health. Soil samples $(10$ to $20 \mathrm{ml})$ were collected from each pot immediately after the end of ASD treatment from a depth of 2.5 to $7.6 \mathrm{~cm}$ using a sterilized metal lab spatula. Soil samples were air dried in sealed 
coin envelopes in a fume hood for $12 \mathrm{~h}$. The impacts of room temperature processing and short-term storage compared with processing/ storage at $-20^{\circ} \mathrm{C}$ or below on microbial community composition and diversity have been shown to be minor (Lauber et al. 2010; Rubin et al. 2013).

Soil $\mathrm{pH}$ was determined using a $1: 1$ by volume dry soil/water mixture using soil collected immediately following ASD treatment.

Soil DNA extraction. DNA was extracted immediately from homogenized soil samples after the brief drying period using the MoBio Powersoil DNA extraction kit (Mobio Laboratories, Inc. Qiagen Company, Carlsbad, CA) with one DNA extraction $(0.25 \mathrm{~g}$ of dry soil) performed per pot.

Effects of ASD on soil bacterial populations. Amplicon libraries were prepared from DNA extracted from soil samples at The Ohio State University OARDC Molecular and Cellular Imaging Center (MCIC, Wooster, OH). Briefly, DNA samples were amplified via PCR using universal primers targeting the V1-V3 regions of the bacterial 16S rRNA gene (Li et al. 2014), and Illumina adapters and spacer regions were added. Illumina Nextera indices were added in a second round of PCR. Following PCR, products were pooled in equimolar ratios for Illumina sequencing. Final amplicon pools were sequenced on the MiSeq platform (Illumina Inc., San Diego, CA) using the MiSeq v3 reagent kit for 300 bp paired end runs.

Quality of sequencing reactions was assessed using FastQC (Andrews 2010). Due to poor quality and insufficient read length in reverse reads, only forward reads were used for analysis with sequences corresponding to the V1-V2 hypervariable regions of the bacterial 16S rRNA gene. A sequencing error led to the loss of nearly a quarter of all samples, but 185 samples were sequenced with a minimum of six sequenced reps per treatment per soil and a minimum of 35 reps of each treatment across the two experimental runs. Illumina adapters and spacers were removed using BBDuk (Joint Genome Institute 2016). DADA2 (version 1.4.0 [Callahan et al. 2016]) was run using $\mathrm{R}$ statistical software (version 3.4.1 [R Core Team 2015]) in order to identify and quantify ribosomal sequence variants (RSV). Sequences were run through a standard DADA2 pipeline with chimera removal following initial primer removal and sequence length trimming to $250 \mathrm{bp}$. Taxonomic assignments were given to each RSV based on the Ribosomal Database Project's 16S rRNA training set (version 16 [Cole et al. 2014]). The R package phyloseq (version 1.20.0 [McMurdie and Holmes 2013]) was used for data visualization, calculation of Shannon's diversity index to assess alpha diversity (diversity within a site), determination of sequence counts per sample, and nonmetric multidimensional scaling (NMDS) of microbiome data using BrayCurtis dissimilarity. Data were normalized using cumulative-sum scaling (CSS) using the R package metagenomeSeq (version 1.18.0
[Paulson et al. 2013]), and normalized data were used for abundance determination of RSV counts, NMDS calculations, and permutational analysis of variance (PERMANOVA). The VEGAN R package (version 2.4.3 [Dixon 2003]) adonis function was used to conduct PERMANOVA with 999 permutations. Seven phyla (Acidobacteria, Actinobacteria, Bacteroidetes, Chloroflexi, Firmicutes, Planctomycetes, and Proteobacteria) were common to all soils and were selected to compare the abundance of select phyla across treatments based on CSS normalized counts.

Quantification of soil populations of Verticillium spp. and Fusarium solani. Soil populations of Verticillium spp. and F. solani immediately following ASD treatment were assessed by qPCR using primers ST-VE1/ITS1-F and AFP346/ITS1-F, respectively (Lievens et al. 2006). Reactions were carried out in $20 \mu \mathrm{l}$ volumes using SSoAdvanced Universal SYBR Green Supermix (Bio-Rad Laboratories, Hercules, CA), $0.5 \mu \mathrm{M}$ of each primer and $2 \mu \mathrm{l}$ of a 1: 10 dilution of template DNA extracted from soils immediately following ASD treatment. Reactions were carried out on a CFX96 real-time PCR system (Bio-Rad Laboratories) using a two-step program consisting of $95^{\circ} \mathrm{C}$ for $5 \mathrm{~min}$ followed by 50 cycles of $95^{\circ} \mathrm{C}$ for $10 \mathrm{~s}$ and $60^{\circ} \mathrm{C}$ for $30 \mathrm{~s}$ and ending with a melt curve from 65 to $95^{\circ} \mathrm{C}$ with a $0.5^{\circ} \mathrm{C}$ increment every $5 \mathrm{~s}$ DNA was quantified based on standard curves of pure pathogen DNA.

Bioassay to assess ASD impacts on plant health. One 4-weekold tomato cultivar Moneymaker seedling (seed source: Everwilde Farms, Bloomer, WI) was planted in each of five pots per treatment containing ASD-treated or control soils 1 week after mulch was removed to end ASD treatment. Six days prior to planting, the uncovered pots were removed from the growth chamber and placed in a greenhouse to allow soil to dry and for dispersion of phytotoxic products produced during ASD. One day prior to planting, soil in each pot was tilled and aerated using a drill bit (SpeedborMax, $3.18 \mathrm{~cm}$ diameter, Irwin Tools, Martinsville, $\mathrm{OH}$ ) attached to a power drill (Kobalt KT200A compact drill, Lowe's Companies, Inc., Mooresville, NC). The drill bit was washed with tap water between each sample and sanitized using a $20 \%$ solution of commercial bleach (final concentration of $1.2 \%$ sodium hypochlorite) followed by two tap water rinses.

Plants were arranged in a randomized complete block design in the greenhouse, just as the pots were arranged in the growth chamber. Plants were fertilized once weekly with a 20-20-20 N-P-K fertilizer (Peter's Professional, ICL Fertilizers, Ltd., Beer Sheva, Israel). Tomatoes were grown in the greenhouse for 6 weeks, and then the plants were harvested, and roots were rinsed in running tap water to remove soil.

Plants were assessed for dry aboveground biomass, root rot severity, taproot rot severity, and nematode damage (galls per root

TABLE 1

Physical and chemical properties of soils from two Ohio counties prior to treatment by anaerobic soil disinfestation

\begin{tabular}{|c|c|c|c|c|c|}
\hline Property & Erie 12 & Erie 21 & Erie 23 & Highland 1 & Highland 2 \\
\hline $\mathrm{pH}^{\mathrm{z}}$ & 7.1 & 6.8 & 7.3 & 7.4 & 7.6 \\
\hline Organic matter (\%) & 1.3 & 1.1 & 1.2 & 2.2 & 1.4 \\
\hline Phosphorus (mg kg ${ }^{-1}$ ) & 149 & 226 & 174 & 268 & 235 \\
\hline Potassium ( $\mathrm{mg} \mathrm{kg}^{-1}$ ) & 67 & 155 & 80 & 220 & 178 \\
\hline Cation exchange capacity $\left(\mathrm{cmol}_{\mathrm{C}} \mathrm{kg}^{-1}\right)$ & 9.7 & 13.7 & 9.7 & 18.9 & 18.9 \\
\hline
\end{tabular}


system). Root rot severity was assessed using the percentage of roots discolored or rotted. Taproot rot severity was assessed using the following subjective 1 to 5 scale: 1 , taproot healthy; 2 , one to two small lesions or slight discoloration on taproot; 3 , multiple lesions covering less than $50 \%$ of the taproot; 4, multiple lesions covering more than $50 \%$ of the taproot; and 5, taproot completely rotted or missing. Root knot nematode galls were counted for each root system. For Highland samples only, gall counts were capped at 100 galls per root system.

A random subsample of lateral roots was collected from each plant, surface sterilized in a $0.6 \%$ solution of sodium hypochlorite for $15 \mathrm{~s}$, rinsed in sterile distilled water and blotted on sterile paper towels, and ten 2- to 5-mm root segments were plated on half strength acidified potato dextrose agar (APDA, BD Difco, Becton, Dickinson, and Company, Franklin Lakes, NJ) and NP10 medium (Kabir et al. 2004). Fungi were identified morphologically following 2 weeks of incubation on APDA and 5 weeks of incubation on NP10 as both $P$. lycopersici and $C$. coccodes have distinct colony morphologies on these media. If a pathogen was present on either medium, that rep was scored as 1 for that pathogen's presence; if a pathogen was not isolated on either medium, then that rep was scored 0 for absent.

Data analysis. Data from both experimental runs were pooled after confirming equal variances (Levene's test). Plant and soil characteristics and qPCR data were analyzed using the following fixed effects general linear model in Minitab (version 17, Minitab Inc., State College, PA): $y=\mu+\operatorname{trt}+$ soil + run $+\operatorname{trt} \times$ soil $+\operatorname{trt} \times$ run + soil $\times$ run $+\operatorname{trt} \times$ soil $\times$ run + block $_{(\text {soil,run })}+\mathrm{e}$, where $\mu$ and $\mathrm{e}$ were the population mean and error terms, respectively, trt was one of five treatments, soil was one of five soils, run was one of two experimental runs, and block was one of five blocks used within each soil and experimental run. Differences in means were assessed using Tukey's honest significant difference with a family-wise error rate of $\alpha=0.05$.

Odds ratios (OR) were calculated from binary and proportional ordinal logistic regression models of fungal incidence data or taproot rot severity, respectively, using SAS statistical software (version 9.4, SAS Institute Inc., Cary, NC). Models were fitted using the LOGISTIC procedure of SAS (Allison 1999; Derr 2013). For proportional odds, an odds ratio equal to one means equal odds of having a root rot severity rating of either 1 or 2 (low severity) versus having a rating of 3,4 , or 5 (moderate to high severity), or conversely equal odds of having a rating of 1, 2, or 3 versus 4 or 5 . For binary odds, an odds ratio of one indicates equal odds of fungal recovery on culture media in the two compared treatments. Odds ratios $>1$ indicate higher odds of fungal isolation for the first treatment in the paired comparison, while odds ratios $<1$ indicate lower odds of fungal isolation for the first treatment in the paired comparison.

Cumulative-sum scaled RSV counts were analyzed within individual soils (data pooled for both experiments within each soil) using the following fixed effects general linear model in Minitab: $\mathrm{y}=\mu+\operatorname{trt}+$ run + block $_{(\text {run })}+\mathrm{e}$, where $\mu$ and e were the population mean and error terms, respectively, trt was the treatment mean, run was the experimental run, and block was the block used within each experimental run. Means were separated as described above.

Pearson's correlation coefficients and associated significance values were calculated in Minitab 17.0.

\section{RESULTS}

Soil pH. Changes in soil $\mathrm{pH}$ following ASD treatment varied across the five soils tested (Table 2). Soil pH only decreased significantly compared with both controls following ASD using ethanol as a carbon source for Erie soils 12 and 23. The overall mean $\mathrm{pH}$ for ethanol-amended soils was significantly lower than mean $\mathrm{pH}$ for any treatment. In general, the highest $\mathrm{pH}$ was observed in soils amended with molasses, and the $\mathrm{pH}$ in these soils was comparable to anaerobic control soils.

Soil reducing conditions. Soil reduction, as indicated by iron oxide paint loss on micro-IRIS rods, in all ASD-treated soils was significantly greater than in the nonamended control soils (Table 3 ). Soil reduction was enhanced significantly in wheat bran- and ethanol-amended soils compared with molasses-amended soils.

Effects of ASD on bacterial community diversity. The alpha diversity of bacterial communities in all five soils following ASD with wheat bran was significantly lower than the alpha diversity of bacterial communities in nonamended control soils (Table 4). Alpha diversity was also significantly reduced following ASD using ethanol in both Highland soils compared with diversity in nonamended control soils. Alpha diversity of soil bacterial communities following ASD using molasses as an amendment did not differ significantly from one or both of the control soils from either farm. Alpha diversity never significantly differed between the two types of controls for any of the five soils. Overnight processing of samples at room temperature may have reduced overall alpha diversity and may have affected rare taxa, but overall community composition and abundance of dominant taxa were likely not changed significantly (Lauber et al. 2010; Rubin et al. 2013).

Effects of ASD on bacterial community composition. Based on the NMDS plot of pooled data from all samples from the Highland

TABLE 2

Mean $\mathrm{pH}$ of five soils from two Ohio counties following anaerobic soil disinfestation with wheat bran, molasses, or ethanol, and in nonamended, anaerobic and aerobic controls

\begin{tabular}{|c|c|c|c|c|c|c|}
\hline Amendment & Erie 12 & Erie 21 & Erie 23 & Highland 1 & Highland 2 & Overall ${ }^{\mathrm{x}}$ \\
\hline Molasses & $7.21 \mathrm{a}$ & $7.09 \mathrm{a}$ & $7.29 \mathrm{a}$ & $7.64 \mathrm{a}$ & $7.68 \mathrm{a}$ & $7.38 \mathrm{a}$ \\
\hline Anaerobic control & $7.09 a b$ & $6.94 \mathrm{~b}$ & $7.20 a b$ & $7.53 a b$ & $7.62 a b$ & $7.28 \mathrm{~b}$ \\
\hline Aerobic control & $6.99 \mathrm{~b}$ & $6.70 \mathrm{c}$ & $7.11 \mathrm{~b}$ & $7.41 \mathrm{c}$ & $7.57 \mathrm{ab}$ & $7.16 \mathrm{c}$ \\
\hline
\end{tabular}


and Erie farms, bacterial communities clustered based on soil and ASD carbon source (Fig. 1A). Bacterial communities from individual soils also clustered based on ASD carbon source (Fig. 1B to F), with one exception being Highland 1 where clustering was less distinct. Communities within individual soils amended with wheat bran were the most dissimilar from communities in control soils. The results of PERMANOVA demonstrated that bacterial communities differed significantly based on ASD treatment $(P=0.001$, $R^{2}$ range: 0.31 to 0.38$)$ within each of the five soils and differed significantly for ASD treatment $\left(P=0.001, R^{2}=0.14\right)$, soil type $\left(P=0.001, R^{2}=0.29\right)$, and the interaction of treatment by soil $\left(P=0.001, R^{2}=0.12\right)$ across all data.

The CSS normalized count-based abundance of the most common bacterial phyla changed following ASD (Table 5). The abundance of Firmicutes increased following ASD in soils amended with wheat bran, with 3.5 to 4.8 times more Firmicutes than in control soils. Firmicutes abundance also increased significantly relative to at least one control, in all soils with the exception of Highland 1 (Table 5). In general, ASD reduced the abundance of Acidobacteria, Actinobacteria, Chloroflexi, and Planctomycetes. The effects of ASD on Bacteroidetes abundance varied depending on soil and carbon source, while the effects of ASD on Proteobacteria abundance ranged from negative to neutral depending on soil and carbon source.

Within Firmicutes, abundance of class Clostridia increased greatly following ASD with any carbon source (Fig. 2, relative abundances of Firmicutes classes in two representative soils are shown). The abundance of Clostridia in wheat bran-amended soils was significantly greater than in nonamended controls for all soils, while the abundance of Clostridia in ethanol-amended soils was significantly greater than in both controls for three soils (Erie 21, Erie 23, and Highland 2). The abundance of class Clostridia was only significantly greater in molasses-amended soils than in control soils for Highland 2, while Clostridia levels were only significantly greater in Erie 21 soils in the anaerobic control compared with levels in the aerobic control. No ASD treatment significantly affected class Bacilli on a consistent basis across soils. The abundance of Negativicutes, a class with many obligate anaerobes, was significantly greater in wheat bran- or ethanol-amended, ASD-treated soils than either control soil for all soils $(P<0.0001$ for all soils).

Effects of ASD on soil populations of Verticillium spp. and F. solani. ASD significantly affected the amount of Verticillium spp. $(P<0.0001)$ and $F$. solani $(P=0.005)$ DNA detected in soil by
qPCR (Fig. 3). The level of detected Verticillium spp. DNA was significantly lower (Fig. 3A) in soils amended with either wheat bran or ethanol compared with molasses-amended and nonamended control soils. Verticillium spp. DNA levels were below the detection threshold in 6 of 50 samples from ethanol-amended soils and 1 of 50 wheat bran-amended soils, and these samples were assigned a value of $10^{-9} \mathrm{ng} / \mu \mathrm{l}$ Verticillium DNA to account for the threshold of detection. Levels of Verticillium spp. DNA were significantly lower in molasses-amended and nonamended, anaerobic soils than in nonamended, aerobic soils. The amount of detected $F$. solani DNA was significantly greater in ethanol-amended soils than in molassesamended and nonamended soils, while the amount of $F$. solani DNA detected in wheat bran-amended soils did not differ significantly from levels in any other soil.

Disease severity and pathogen incidence. Root rot severity was significantly lower in plants from wheat bran- and ethanol-amended, ASD-treated soils compared with the molasses-amended soils and controls (Table 3). Significantly fewer nematode galls were found on plants grown in any ASD-treated soil than from plants from nonamended control soils (Table 3). Both M. hapla and M. incognita were sensitive to ASD treatments. Levels of nematode galling did not differ significantly between ASD carbon sources.

Taproot rot severity also varied in plants grown in soils amended with different carbon sources. Approximately $70 \%$ of plants from either wheat bran- or ethanol-amended, ASD-treated soils had

TABLE 4

Shannon's diversity index for bacterial communities in five soils following anaerobic soil disinfestation using one of three carbon sources (wheat bran, molasses, or ethanol) and in nonamended, anaerobic and aerobic controls

\begin{tabular}{lccccc}
\hline Amendment & Erie 12 & Erie 21 & Erie 23 & Highland 1 & Highland 2 \\
\hline Wheat bran & $5.38 \mathrm{c}^{\mathrm{y}}$ & $5.24 \mathrm{~b}$ & $5.37 \mathrm{c}$ & $5.60 \mathrm{~b}$ & $5.65 \mathrm{bc}$ \\
\hline Molasses & $5.60 \mathrm{bc}$ & $5.47 \mathrm{ab}$ & $5.82 \mathrm{ab}$ & $5.85 \mathrm{ab}$ & $5.95 \mathrm{ab}$ \\
\hline Ethanol & $5.82 \mathrm{ab}$ & $5.74 \mathrm{a}$ & $5.61 \mathrm{bc}$ & $5.21 \mathrm{c}$ & $5.44 \mathrm{c}$ \\
\hline Anaerobic control & $6.11 \mathrm{a}$ & $5.90 \mathrm{a}$ & $5.92 \mathrm{a}$ & $6.18 \mathrm{a}$ & $6.24 \mathrm{a}$ \\
\hline Aerobic control $^{2}$ & $5.92 \mathrm{ab}$ & $5.87 \mathrm{a}$ & $5.87 \mathrm{ab}$ & $6.17 \mathrm{a}$ & $6.32 \mathrm{a}$ \\
\hline$P$ value $^{\mathrm{z}}$ & $<0.0001$ & $<0.0001$ & $<0.0001$ & $<0.0001$ & $<0.0001$ \\
\hline
\end{tabular}

$\mathrm{y}$ Mean values in a column sharing the same letter do not differ

significantly at $\alpha=0.05$.

z Analysis of variance $P$ value.

TABLE 3

Soil reducing conditions, dry matter of shoots and roots, root rot severity, and nematode damage in tomatoes grown in soils following anaerobic soil disinfestation with wheat bran, molasses, or ethanol, or in nonamended, anaerobic and aerobic controls ${ }^{v}$

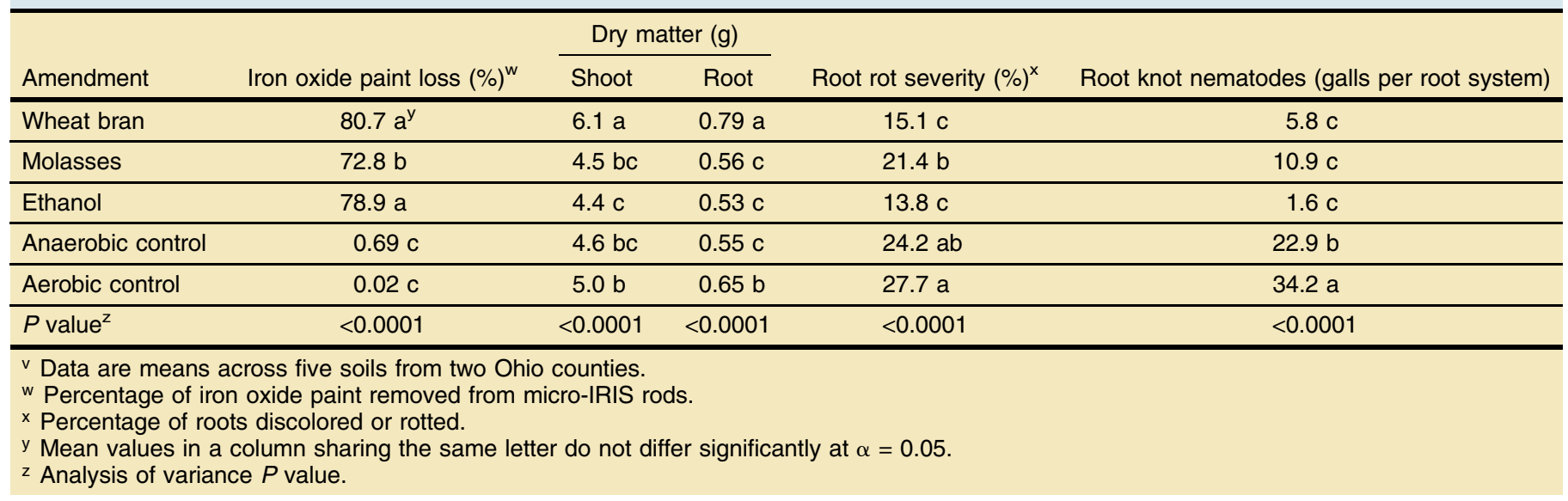


a taproot rot severity rating of 2 or below (meaning low to no taproot rot), while only $38 \%$ of plants from molasses-amended soils had similar low taproot rot severity ratings (Fig. 4A). Fewer plants from control soils had low taproot rot severity ratings, with low ratings for only $22 \%$ of plants from anaerobic controls and $32 \%$ of plants from aerobic controls. The odds of having significantly higher taproot rot severity ratings in bioassay plants were significantly affected by ASD carbon source $(P<0.0001$, Fig. 4B). Plants from
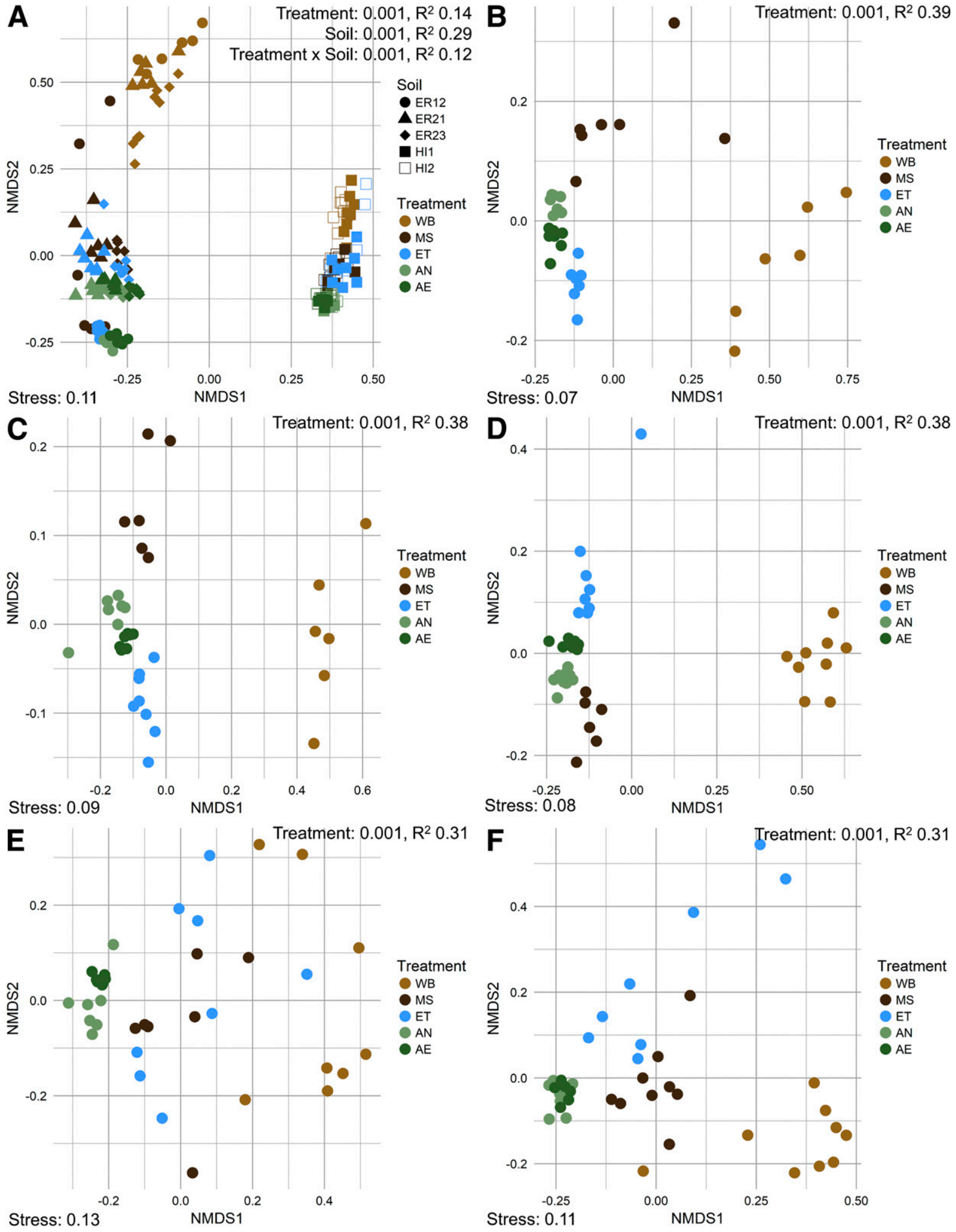

Fig. 1. Nonmetric multidimensional scaling (NMDS) plots based on Bray-Curtis dissimilarity of soil bacterial community data from five soils from two Ohio counties (Erie [ER] and Highland [HI]) following anaerobic soil disinfestation using one of three carbon sources (WB, wheat bran; MS, molasses; and ET, ethanol) and nonamended, anaerobic and aerobic controls (AN, anaerobic control; and AE, aerobic control). NMDS plots are shown for A, combined location data, B, Erie 12, C, Erie 21, D, Erie 23, E, Highland 1, and F, Highland 2. Stress values for NMDS are shown in the lower left, while permutational analysis of variance $P$ values and $R^{2}$ values are shown in the upper right of each plot. 
all treatments, including the aerobic control, had significantly lower odds of having a moderate-high taproot rot severity rating than plants from the anaerobic control (Fig. 4B). Plants from soils amended with either wheat bran or ethanol also had significantly lower odds of having a moderate-high taproot rot severity rating than plants from aerobic or anaerobic controls. Plants from molasses-amended soils were approximately two times more likely to have a moderate-high taproot rot severity rating than plants from ethanol-amended soils. Plants from wheat bran-amended soils were less likely $(\mathrm{OR}=0.25)$ to have a higher severity rating than plants from molasses-amended soils. The odds of increased taproot rot severity ratings did not differ between the ethanol and wheat bran treatments.

The frequency of isolating fungal pathogens from roots varied with ASD treatment. Colletotrichum coccodes was isolated from only 9 of 49 plants (18\%) grown in ethanol-treated soils, but was isolated from 40 of 49 plants (82\%) from anaerobic control soils (Fig. 5A). Pyrenochaeta lycopersici was isolated from half of the plants grown in wheat bran-amended, ASD-treated soils, while the same fungus was isolated from 39 plants (80\%) from anaerobic

TABLE 5

Abundance based on cumulative-sum scaling normalized sequence counts of seven bacterial phyla in five soils from two Ohio counties following anaerobic soil disinfestation using one of three carbon sources (wheat bran, molasses, or ethanol) and in nonamended, anaerobic and aerobic controls ${ }^{2}$

\begin{tabular}{|c|c|c|c|c|c|c|c|}
\hline Soil and amendment & Acidobacteria & Actinobacteria & Bacteroidetes & Chloroflexi & Firmicutes & Planctomycetes & Proteobacteria \\
\hline \multicolumn{8}{|l|}{ Erie 12} \\
\hline Wheat bran & $45 c^{*}$ & $57 c^{*}$ & $83 a b^{\star \star *}$ & $21 c^{*}$ & $755 a^{\star \star \star \star *}$ & $36 c^{*}$ & $346 c^{*}$ \\
\hline Ethanol & $134 b^{*}$ & $266 a^{\star \star *}$ & $56 b^{* * *}$ & $69 b^{*}$ & $361 \mathrm{~b}^{\star \star \star \star}$ & $139 b^{*}$ & $458 a^{a b c} c^{\star \star *}$ \\
\hline Anaerobic control & $229 a$ & $196 \mathrm{ab}$ & $62 \mathrm{~b}$ & $125 \mathrm{a}$ & $194 \mathrm{bc}$ & $195 a$ & $557 a$ \\
\hline \multicolumn{8}{|l|}{ Erie 21} \\
\hline Wheat bran & $41 b^{*}$ & $84 b^{*}$ & $59 \mathrm{~b}^{\star \star \star}$ & $20 c^{*}$ & $765 a^{\star \star \star \star \star}$ & $55 c^{\star}$ & $296 b^{*}$ \\
\hline Molasses & $77 a b^{\star \star \star}$ & $116 b^{*}$ & $135 a^{\star \star \star}$ & $106 a b^{\star \star \star}$ & $239 c^{\star \star \star \star}$ & $135 b^{\star *}$ & $551 a^{\star \star \star}$ \\
\hline Ethanol & $88 a^{\star \star \star}$ & $217 a^{\star \star \star}$ & $70 b^{\star \star \star}$ & $68 b^{\star *}$ & $405 b^{\star \star \star \star \star}$ & $133 b^{\star \star}$ & $505 a^{\star \star \star}$ \\
\hline \multicolumn{8}{|l|}{ Erie 23} \\
\hline Wheat bran & $45 b^{*}$ & $67 d^{*}$ & $74 b^{\star \star *}$ & $25 c^{*}$ & $726 a^{\star \star \star \star \star}$ & $76 c^{\star}$ & $321 c^{*}$ \\
\hline Molasses & $94 a^{\star \star \star}$ & $105 \mathrm{~cd}^{\star \star}$ & $165 a^{\star \star \star \star \star}$ & $142 a^{\star \star \star}$ & $281 \mathrm{bc}^{\star \star \star \star}$ & $172 b^{\star *}$ & $444 b^{*}$ \\
\hline Ethanol & $93 a^{\star \star \star}$ & $170 a b^{\star \star \star}$ & $108 b^{\star \star \star}$ & $70 b^{*}$ & $308 b^{\star \star \star \star \star}$ & $145 b^{\star \star}$ & $467 a b^{\star \star \star}$ \\
\hline Anaerobic control & $118 \mathrm{a}$ & $143 \mathrm{bc}$ & $97 \mathrm{~b}$ & $135 \mathrm{a}$ & $207 \mathrm{~cd}$ & $192 b$ & $502 a b$ \\
\hline Aerobic control & $117 \mathrm{a}$ & $193 \mathrm{a}$ & $96 \mathrm{~b}$ & $113 \mathrm{a}$ & $125 d$ & 249 a & $521 \mathrm{a}$ \\
\hline$P$ value & $<0.0001$ & $<0.0001$ & $<0.0001$ & $<0.0001$ & $<0.0001$ & $<0.0001$ & $<0.0001$ \\
\hline \multicolumn{8}{|l|}{ Highland 1} \\
\hline Wheat bran & $53 c^{*}$ & $37 d^{*}$ & $155 \mathrm{a}^{\star \star \star \star}$ & $31 d^{*}$ & $529 a^{\star \star \star \star \star}$ & $86 c^{*}$ & $535^{\star \star \star}$ \\
\hline Wheat bran & $63 b^{*}$ & $37 c^{*}$ & $151 \mathrm{a}^{\star \star \star \star \star}$ & $24 d^{*}$ & $650 a^{\star \star \star \star *}$ & $108 d^{*}$ & $498 c^{\star *}$ \\
\hline Molasses & $90 \mathrm{~b}^{*}$ & $71 b^{\star *}$ & $133 a b^{\star \star \star}$ & $69 \mathrm{bc}^{\star *}$ & $373 b^{\star \star \star \star \star ~}$ & $193 b^{\star \star *}$ & $627 a^{\star \star \star *}$ \\
\hline Ethanol & $82 b^{*}$ & $81 b^{* *}$ & $131 a b^{\star \star \star}$ & $55 c^{*}$ & $454 b^{\star \star \star \star \star *}$ & $155 \mathrm{~cd}^{*}$ & $562 \mathrm{bc}^{\star \star}$ \\
\hline Anaerobic control & $157 \mathrm{a}$ & $87 \mathrm{~b}$ & $108 \mathrm{~b}$ & $90 a b$ & $122 \mathrm{c}$ & $251 \mathrm{~b}$ & $711 \mathrm{a}$ \\
\hline Aerobic control & $126 \mathrm{a}$ & $153 \mathrm{a}$ & $102 \mathrm{~b}$ & $112 \mathrm{a}$ & $135 c$ & $325 \mathrm{a}$ & $625 a b c$ \\
\hline$P$ value & $<0.0001$ & $<0.0001$ & 0.004 & $<0.0001$ & $<0.0001$ & $<0.0001$ & 0.001 \\
\hline
\end{tabular}


control soils. Recovery of both pathogens from roots was lowest for plants grown in ethanol-amended, ASD-treated soils. Both pathogens were isolated from eight of 49 plants (16\%) grown in soils amended with ethanol versus 31 of 49 plants (63\%) grown in anaerobic control soils. Neither pathogen was isolated from roots of
19 of 49 plants (39\%) grown in soils treated with ethanol. In contrast, neither pathogen was isolated from only one plant in aerobic control soils. The odds of isolating $C$. coccodes $(P<$ $0.0001)$, $P$. lycopersici $(P=0.013)$, both pathogens $(P=0.0002)$, or neither pathogen $(P=0.0002)$ from an individual plant were
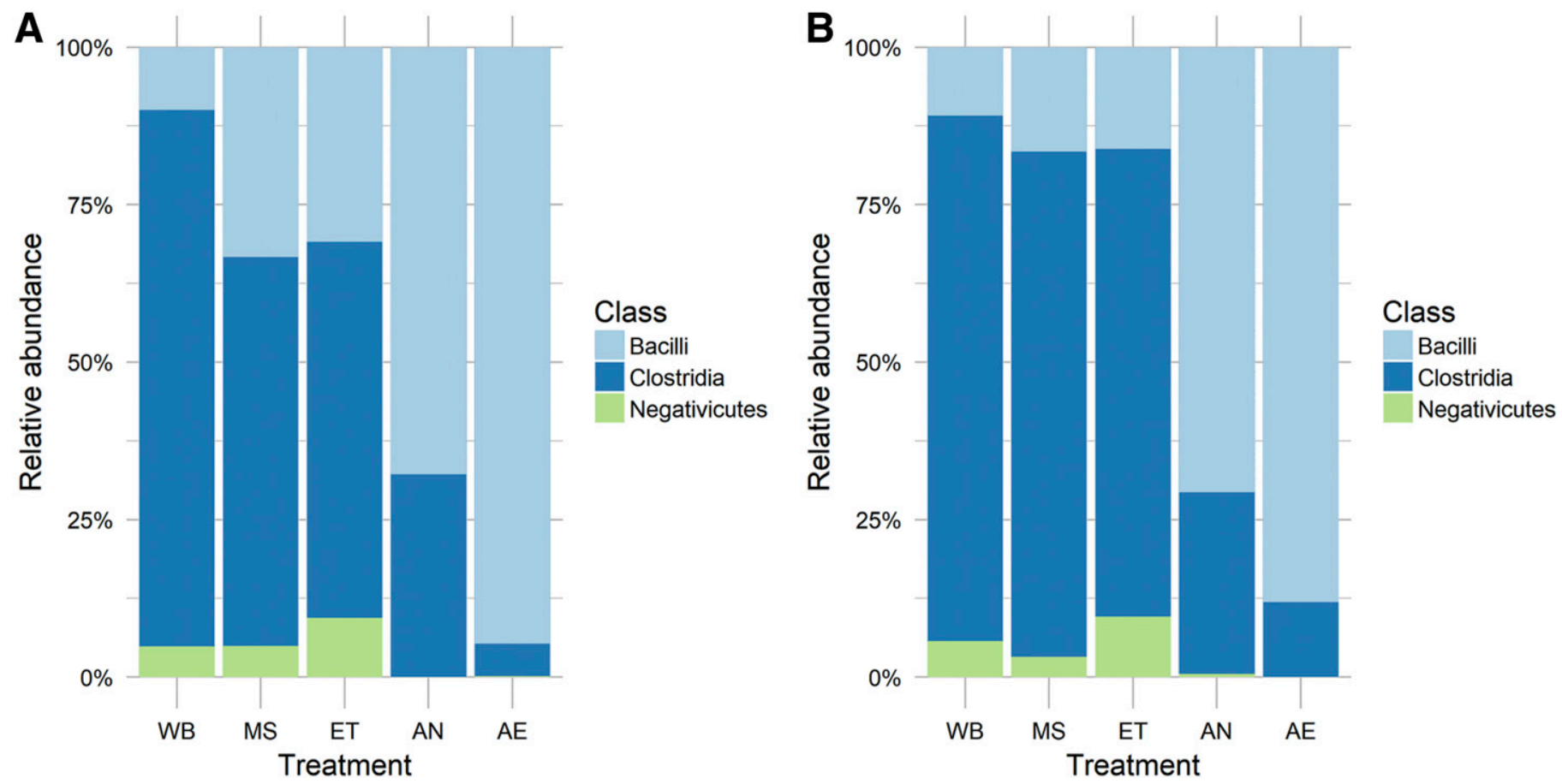

Fig. 2. Relative abundance of three classes of Firmicutes in two representative soils, A, Erie 12 and $\mathbf{B}$, Highland 1, following treatment with anaerobic soil disinfestation with one of three carbon sources (wheat bran [WB], molasses [MS], and ethanol [ET]) or in nonamended, anaerobic (AN) or aerobic (AE) control soils.
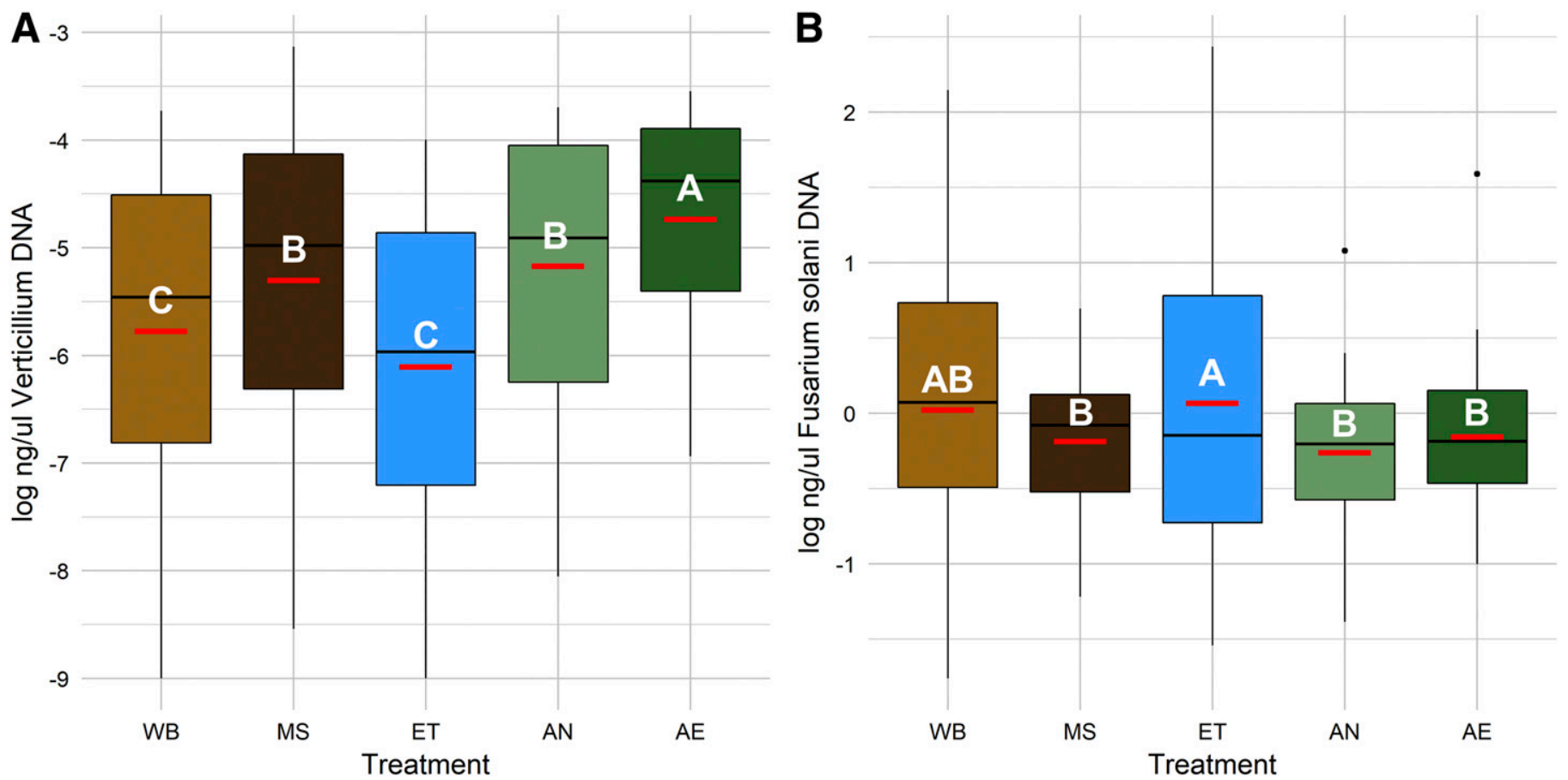

Fig. 3. Relative amount of A, Verticillium spp. or B, Fusarium solani DNA as indicated by quantitative PCR in soils treated with anaerobic soil disinfestation with one of three carbon sources (wheat bran [WB], molasses [MS], and ethanol [ET]) or in nonamended, anaerobic (AN) or aerobic (AE) control soils. Red bars indicate the treatment means. Mean values that share the same letter do not differ significantly based on Tukey's honest significant difference test with a family-wise error rate of $\alpha=0.05$. 
significantly affected by ASD carbon source (Fig. 5B to E). There were significantly lower odds of isolating $C$. coccodes from plants from molasses- or ethanol-amended, ASD-treated soils than from plants from anaerobic control soils (Fig. 5B). There were also significantly lower odds of isolating $C$. coccodes from plants from ethanol-amended soils than from plants grown in aerobic control soils. The odds of isolating $C$. coccodes from plants from wheat bran- or molasses-amended soils were higher (wheat bran: OR = 8.6, molasses: $\mathrm{OR}=5.7$ ) than from plants grown in ASD-treated soils amended with ethanol. No ASD carbon source significantly decreased the odds of isolating $P$. lycopersici from bioassay plants compared with the aerobic control (Fig. 5C), but the odds of isolating $P$. lycopersici were significantly lower for plants from soils amended with either wheat bran or ethanol than from plants grown in anaerobic control soils. The odds of isolating $P$. lycopersici were significantly lower for plants from wheat bran-amended soils than from molasses-amended soils. ASD with any of the carbon sources led to significantly lower odds of isolating both C. coccodes and P. lycopersici from an individual plant (Fig. 5D) compared with plants from anaerobic control soils, and the odds
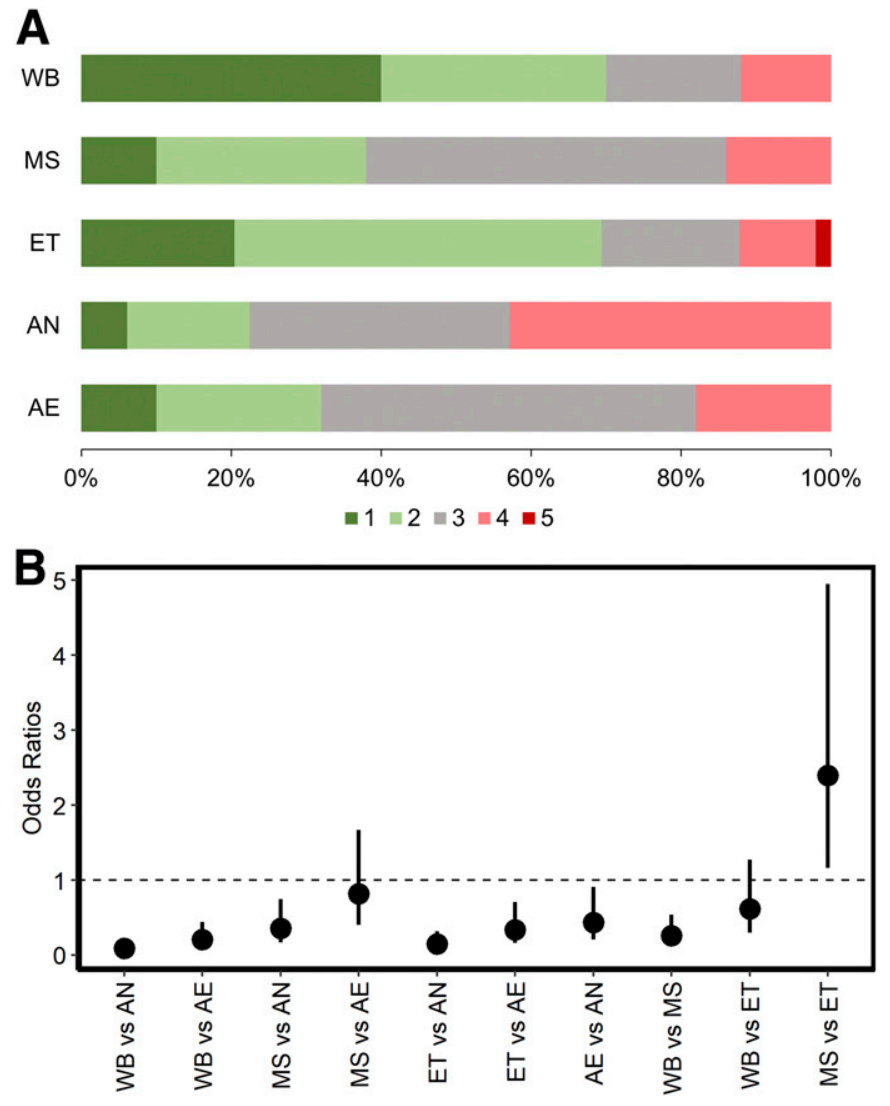

Fig. 4. A, Percentage of tomato plants with a given taproot rot severity rating grown in soils treated with anaerobic soil disinfestation using one of three carbon sources (wheat bran [WB], molasses [MS], and ethanol [ET]) or in nonamended, anaerobic (AN) or aerobic (AE) control soils. B, Odds ratios (dots) and $95 \%$ confidence intervals (lines) are shown from proportional ordinal logistic regression the association of taproot rot severity and treatment. The dotted line indicates a proportional odds ratio of 1 meaning equal odds of taproot rot severity ratings between two compared treatments. Taproots were rated as follows: 1 , taproot healthy (dark green); 2, one to two small lesions present or slight discoloration on taproot (light green); 3 , multiple lesions present covering less than $50 \%$ of the taproot (gray); 4, multiple lesions present covering more than $50 \%$ of the taproot (pink); and 5, taproot completely rotten or missing (scarlet). were significantly lower for plants from soils subjected to ASD with the ethanol amendment than the aerobic control. The odds of isolating both fungi from a plant from molasses-amended soils were significantly higher than from a plant from ethanol-amended soils, while the odds of isolating both fungi did not differ significantly for plants from wheat bran- or ethanol-amended soils. The odds of isolating neither pathogen from an individual plant (Fig. 5E) were significantly higher for the ethanol $(\mathrm{OR}=27.8)$ and wheat bran $(\mathrm{OR}=10.5)$ amendments than from plants grown in anaerobic control soils and were also significantly higher for plants from ethanol-amended soils than from plants grown in aerobic control soils. The odds of isolating neither pathogen from plants from wheat bran- or molasses-amended soils were significantly lower than from plants grown in ethanol-amended soils.

Plant biomass. The dry shoot and root biomasses of plants grown in wheat bran-amended soils were significantly greater than for plants grown in any other ASD-treated or control soils (Table 3). Dry shoot and root biomasses were significantly lower for plants grown in ethanol-amended soils compared with those of plants grown in aerobic control soils.

Correlation between potential ASD mechanisms and disease severity. The percentage of iron oxide paint lost on IRIS tubes was strongly, negatively correlated with root rot severity and moderately negatively correlated with root knot nematode galling (Table 6). Soil $\mathrm{pH}$ was moderately positively correlated with both root rot severity and nematode galling. Weak and nonsignificant correlations were observed for the relationship of Acidobacteria, Actinobacteria, Bacteroidetes, and Chloroflexi abundance with both disease severity indicators. The abundance of Firmicutes was moderately negatively correlated with both root rot severity and nematode galling, while Planctomycetes abundance was moderately positively correlated with both root rot and nematode galling. The abundance of Proteobacteria was moderately positively correlated with root rot severity and weakly positively correlated with nematode galling.

\section{DISCUSSION}

Growers producing vegetables in protected culture systems in temperate climates have few available soilborne disease management options, and the results of this study show that ASD may be an effective tool for management of a broad range of soilborne pathogens. ASD is ideally suited for implementation in protected culture due to the high value of crops, particularly tomatoes, produced in these structures, as well as the need for intervention resulting from lack of crop rotation. ASD was initially developed under temperate conditions in the Netherlands, yet no ASD research has been conducted in the temperate Midwestern region of the United States. This study contributes to a better understanding of the efficacy of ASD treatment in Midwestern soils, in which dominant soil types, such as Mollisols, Alfisols, and Spodosols, and cropping histories differ from those present in other regions of the United States where ASD has been tested.

We sought to determine the differential impacts of three distinct carbon sources on four soilborne diseases as pathogens differ in their sensitivity to ASD treatments. An improved understanding of carbon source-dependent impacts on soilborne pathogens would aid in future prescriptive recommendations for growers deploying ASD against specific soilborne diseases. The carbon sources evaluated in this study were selected due to their historical use in ASD experiments (Katase et al. 2009; Momma et al. 2010, 2013) and availability to growers, and because each represents a unique form of carbon. The carbon in molasses is in the form of sugars readily available for soil microbes, and the use of molasses to support soil 
microbial communities is well established (Welbaum et al. 2004). Wheat bran is a complex carbon source, with carbon in the form of complex polysaccharides, such as cellulose. Ethanol, the simplest carbon form in this study, represents an alcohol form of carbon amendment that has been examined extensively in ASD studies in Japan (Momma et al. 2010).

We examined how these ASD carbon sources shape soil bacterial communities following ASD as breakdown of each carbon source
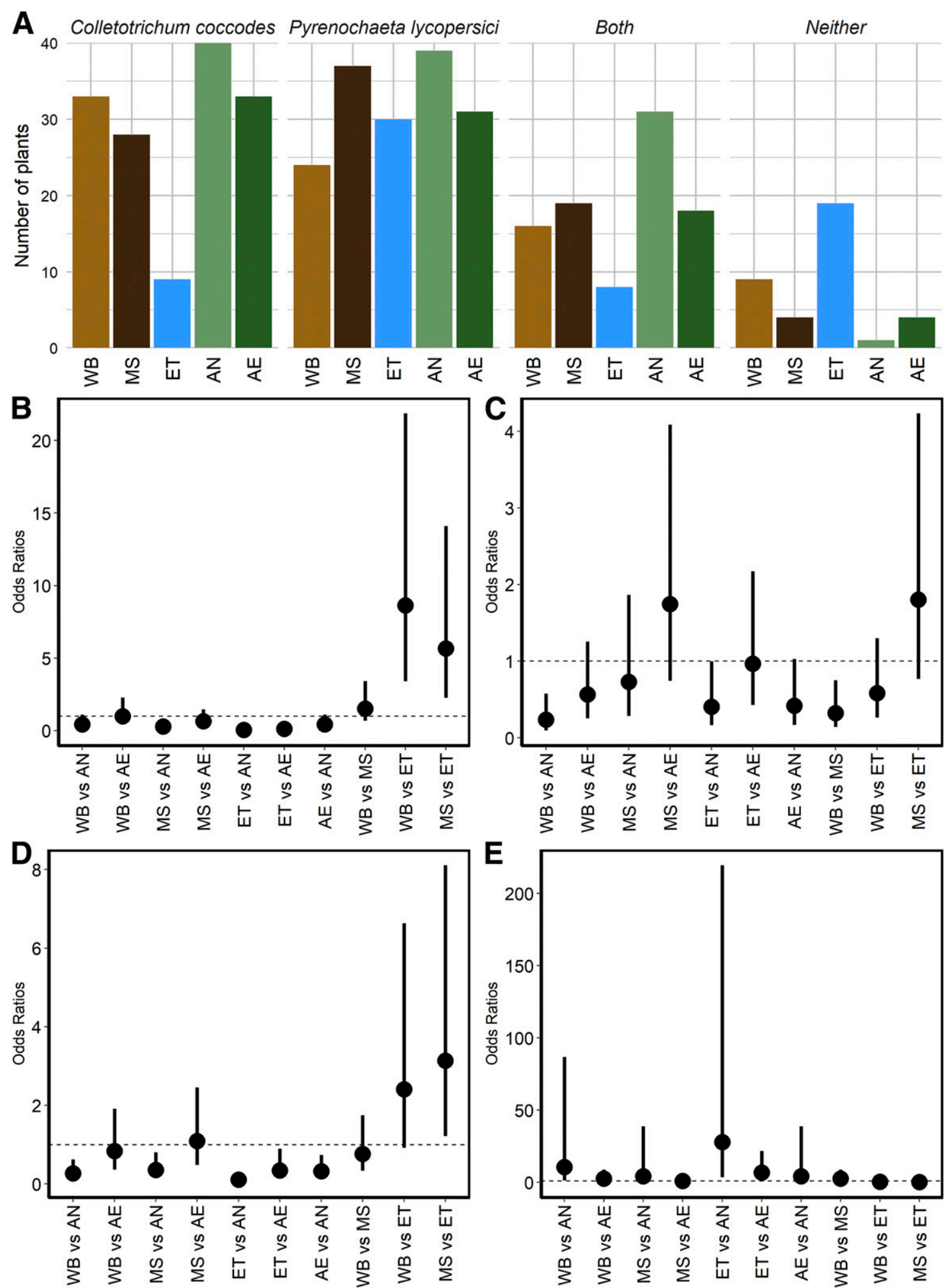

Fig. 5. A, The number of plants grown in soils treated with anaerobic soil disinfestation with one of three carbon sources (wheat bran [WB], molasses [MS], and ethanol [ET]) or either nonamended, anaerobic (AN) or aerobic (AE) controls, from which Colletotrichum coccodes, Pyrenochaeta lycopersici, both fungi, or neither fungi were isolated; $n=50$ plants per treatment, ET and NC, $n=49$ plants per treatment. B to E, Odds ratios from binary logistic regression of the association between the incidence of fungal isolation and treatment for $\mathbf{B}, \mathbf{C}$. coccodes, $\mathbf{C}, P$. lycopersici, $\mathbf{D}$, both pathogens, or $\mathbf{E}$, neither pathogen and treatment. The dotted line indicates an odds ratio of 1 , meaning no difference in the odds of fungal isolation between two treatments. 
should be mediated by a different succession of microbes. ASD is a microbially driven process, and the findings of this study support the concept that carbon sources shape soil microbial community structure following ASD. Microbial community composition following ASD is differentiated by carbon source as demonstrated in this and previous studies (Hewavitharana and Mazzola 2016). Changes in alpha diversity and community composition occurred in our experiments in a soil- and carbon source-dependent manner. Firmicutes abundance was negatively correlated with both root rot severity and nematode galling, and the abundance of class Clostridia, all obligate anaerobes, increased significantly in all ASD treatments in this study. Clostridium spp. produce many byproducts in anaerobic respiration, and their key role in ASD is well established (Mowlick et al. 2013a; Strauss and Kluepfel 2015; Ueki et al. 2017). ASD reduced the abundance of members of Acidobacteria, Actinobacteria, Chloroflexi, and Planctomycetes in multiple soils in this study, and these phyla have also been reported to decrease following ASD in orchard and flower bulb production systems (Hewavitharana and Mazzola 2016; van Agtmaal et al. 2015).

Carbon sources shape the microbial communities that drive the antipathogen factors of ASD that lead to death or inactivation of pathogen propagules: anaerobicity (Ebihara and Uematsu 2013), organic acid production (Momma et al. 2006), production of toxic gasses (Runia et al. 2014) and volatiles (Hewavitharana et al. 2014), and proliferation of microbes capable of degrading pathogen structures (Ueki et al. 2017). Differential production of these ASD antipathogen factors could account for differential control of soilborne pathogens. Use of wheat bran and ethanol led to the strongest reducing conditions in soils, and a moderate correlation between iron oxide paint loss and disease severity indicators suggests this could potentially account for differential disease control compared with molasses treatment. Use of wheat bran in ASD results in production of organic acids, including acetic and butyric acid (Katase et al. 2009; Momma et al. 2006), while the use of ethanol as a carbon source can lead to accumulation of acetic acid (Momma et al. 2010). No published reports could be found of acetic or butyric acid production due to molasses amendment in ASD treatments. Decreases in $\mathrm{pH}$ have been reported to occur during ASD (Butler et al. 2012b; Momma et al. 2006), but a decrease in $\mathrm{pH}$ was not observed consistently in this study, possibly due to edaphic factors. The anaerobic degradation of each carbon source leads to a unique combination of gasses (Lamers et al. 2010; Runia et al. 2014) and volatiles (Hewavitharana et al. 2014), and these differences were noticeable enough that ASD carbon sources could be distinguished by odor alone following ASD treatment in this study

TABLE 6

Correlation coefficients and probability values

in parentheses between the percentage of iron oxide paint lost, soil $\mathrm{pH}$, and abundances of common bacteria phylum and two disease severity indicators: root rot severity and nematode galling

\begin{tabular}{lcc}
\hline Variable & Root rot severity & Nematode galls \\
\hline \% Iron oxide paint loss & $-0.581(<0.0001)$ & $-0.371(<0.0001)$ \\
\hline $\mathrm{pH}$ & $0.466(<0.0001)$ & $0.468(<0.0001)$ \\
\hline Acidobacteria & $0.293(<0.0001)$ & $0.031(0.7)$ \\
\hline Actinobacteria & $-0.054(0.5)$ & $-0.141(0.06)$ \\
\hline Bacteroidetes & $0.210(0.004)$ & $0.002(1)$ \\
\hline Chloroflexi & $0.289(<0.0001)$ & $0.095(0.2)$ \\
\hline Firmicutes & $-0.462(<0.0001)$ & $-0.345(<0.0001)$ \\
\hline Planctomycetes & $0.488(<0.0001)$ & $0.429(<0.0001)$ \\
\hline Proteobacteria & $0.447(<0.0001)$ & $0.291(<0.0001)$ \\
\hline
\end{tabular}

(data not shown). The impacts of these different gas and volatile combinations on specific pathogens still needs to be determined. An emerging mechanism of ASD is direct antagonism of pathogens by microbes that proliferate during ASD treatment, such as Clostridium beijerinckii strains that are capable of degrading fungal cell walls (Ueki et al. 2017). Further studies need to be conducted to determine how different carbon sources differ in their production of each antipathogen factor of ASD.

Previous work suggested that ASD carbon sources have differential efficacies against different soilborne pathogens (Shennan et al. 2014), and in turn, plant health, and evidence to support this hypothesis is provided in this study. Fungal pathogens varied in sensitivity to carbon sources. C. coccodes was most sensitive to ethanol, while $P$. lycopersici appeared most sensitive to wheat bran. Plants from soils amended with either molasses or ethanol had reduced odds of $C$. coccodes isolation from their root systems compared with controls, while plants from soils amended with either wheat bran or ethanol had reduced odds of P. lycopersici isolation from their root system compared with controls. Soil populations of Verticillium spp. were differentially affected by ASD, with ethanol and wheat bran being the most effective in reducing Verticillium spp. levels compared with controls. Soil populations of $F$. solani did not decrease following ASD, and for ethanol-amended soils, were significantly higher than populations in control soils. However, it is unclear if this change would be biologically significant. Nematodes appear to be most sensitive to ASD, as all ASD carbon sources effectively reduced root knot nematode galling in tomato plants. It is unclear if the reduction in nematode galling is due solely to the development of anaerobic conditions, as molasses amendments have nematicidal effects against root knot nematodes even without anaerobic conditions (Rodriguez-Kabana and King 1980; Vawdrey and Stirling 1997).

Differential impacts of ASD carbon sources were also observed on plant health. Biomass increase in plants following ASD has been shown to be a carbon source-dependent phenomenon (Hewavitharana and Mazzola 2016) and not necessarily associated with reduced disease. Wheat bran was the only ASD carbon source associated with significantly increased root and shoot biomass, while also significantly reducing root rot severity. The use of ethanol as an ASD carbon source consistently reduced root rot severity, and ethanol has proven to be effective against fungi and oomycetes, including Fusarium and Pythium, in previous studies (Hewavitharana et al. 2014; Momma et al. 2010). Use of ethanol as an ASD carbon source led to biomass levels that were equivalent or reduced compared with controls. Both ethanol and wheat bran were significantly associated with reduced taproot rot severity compared with nontreated controls. Taproot rot can be more damaging to plant growth than lateral root rot (Campbell and Neher 1994), and this seems to be especially relevant for management of corky root rot (Campbell et al. 1982; Shishkoff and Campbell 1990).

No pathogen was completely eliminated in our ASD trials, and the practical question remains of how to improve the efficacy of ASD as a tool for management of soilborne diseases in tomato production. The efficacy of ASD depends on multiple decisions in the treatment application process including tarping period, timing treatments for soil temperature, and carbon source. Treatment efficacy increases with temperature (Shennan et al. 2018) and tarping period (Shennan et al. 2014), so one manner in which treatment could be improved is to treat soils for longer periods of time (4 to 6 weeks) when soil temperatures are the highest. However, higher soil temperatures occur during peak growing times, and grower adoption of ASD technologies is thereby constrained to when applications fit into their production schedules. The focus for optimizing ASD in protected culture tomato production systems 
should emphasize determining the most effective carbon sources, rates, or combination of carbon sources in order to improve disease control in time- and temperature-constrained production schedules. The $\mathrm{C}: \mathrm{N}$ ratio has been emphasized in other research as a way to find ideal ASD carbon sources (Shrestha et al. 2018). Dutch studies of ASD led to the development of the high protein propriety ASD carbon source "Herbie" (Thatchtec BV [Meints and Feil 2017; Runia et al. 2014]). Higher protein carbon sources rich in cysteine, such as soybean meal, could potentially lead to enhanced generation of antipathogen levels of hydrogen sulfide in certain soils. Ethanol, however, has proven effective as an ASD carbon source in this and other ASD studies (Hewavitharana and Mazzola 2016; Momma et al. 2010). Ethanol application had the lowest overall carbon input (1.9 $\mathrm{mg}_{\mathrm{g}} \mathrm{C} \mathrm{g}^{-1}$ of soil), and ethanol has no nitrogen in its structure. This again suggests differential production of ASD antipathogen factors. Combinations of carbon sources may be necessary to treat soilborne disease complexes effectively. Different carbon sources produce different suites of antipathogen factors during ASD, and combining carbon sources that effectively control different pathogens independently may lead to improved control of multiple pathogens. For example, a combination of wheat bran and ethanol could potentially lead to enhanced control of both $C$. coccodes and $P$. lycopersici compared with independent use of either carbon source.

The development of anaerobic conditions has been shown to be necessary for successful ASD treatments (Shennan et al. 2018), and in this study we introduced a low-cost tool, micro-IRIS rods, for assessing these conditions in soils. This represents a novel adaptation of IRIS tubes, which were originally developed to assess reducing conditions in wetland soils (Rabenhorst 2008). IRIS tubes and micro-IRIS rods have advantages over oxidation-reduction potential (ORP) probes in that they are less expensive than probes, do not require electricity or logging equipment, and can be used to assess reducing conditions at various depths. All carbon sources used in this study as amendments led to the development of reducing conditions in the soil as indicated by micro-IRIS rods, and the relative loss of iron oxide paint on rods was sensitive enough to indicate differences in reducing conditions between carbon sources.

The "white whale" of ASD research is to identify the exact mechanisms by which pathogens are killed or inactivated. We do not fully understand which specific antipathogen factors (anaerobicity, organic acids, etc.) make root knot nematodes highly sensitive to ASD or certain fungi more resilient than others to ASD. We can use the pathogens present in the soilborne disease complex as a model for differential sensitivity to ASD antipathogen factors. We also need to shift focus to examine the dynamic nature of ASD treatment. The majority of studies of the effects of ASD on soil microbes and antipathogen factors have focused on the final soil state following ASD treatment. There is a need to conduct time course experiments on real-time shifts in soil microbial communities, with consideration for relic DNA (Carini et al. 2016), and antipathogen factors during the process of ASD, in order to develop a better understanding of which microbes may be most responsible for the development of these factors.

ASD is a complex method of soilborne disease management, dependent on the interactions of highly variable biological, chemical, and physical conditions in soils. This study represents an assessment of ASD as a tool for management of the soilborne disease complex in protected culture tomato production and provides strong evidence for the differential impacts of ASD carbon sources on soilborne pathogens, soil bacterial communities, and plant health. The findings of this study contribute to our understanding of the complex biological interactions that occur in soil ecosystems and will be used to develop optimized ASD treatments for growers' use, providing them with improved disease management options. Future practical work must focus on optimizing carbon source rates and combinations in order to improve management of all members of the soilborne disease complex and to provide clearer management recommendations to tomato growers.

\section{ACKNOWLEDGMENTS}

We thank M. Moodispaw and N. Khatri for assistance with the ASD trials and S. Wijeratne (OSU OARDC MCIC Computational Biology Laboratory) and S. Debenport for assistance with bioinformatics. We thank our grower collaborators for their cooperation and soil samples.

\section{LITERATURE CITED}

Allison, P. D. 1999. Logistic Regression Using the SAS System: Theory and Application. SAS Institute Inc., Cary, NC.

Andrews, S. 2010. FastQC: A quality control tool for high throughput sequence data. Cambridge, UK. http://www.bioinformatics.babraham.ac.uk/projects/fastqc.

Blok, W. J., Lamers, J. G., Termorshuizen, A. J., and Bollen, G. J. 2000. Control of soilborne plant pathogens by incorporating fresh organic amendments followed by tarping. Phytopathology 90:253-259.

Butler, D. M., Kokalis-Burelle, N., Muramoto, J., Shennan, C., McCollum, T. G., and Rosskopf, E. N. 2012a. Impact of anaerobic soil disinfestation combined with soil solarization on plant-parasitic nematodes and introduced inoculum of soilborne plant pathogens in raised-bed vegetable production. Crop Prot. 39: 33-40.

Butler, D. M., Rosskopf, E. N., Kokalis-Burelle, N., Albano, J. P., Muramoto, J., and Shennan, C. 2012b. Exploring warm-season cover crops as carbon sources for anaerobic soil disinfestation (ASD). Plant Soil 355:149-165.

Callahan, B. J., McMurdie, P. J., Rosen, M. J., Han, A. W., Johnson, A. J. A., and Holmes, S. P. 2016. DADA2: High-resolution sample inference from Illumina amplicon data. Nat. Methods 13:581-583.

Campbell, C. L., and Neher, D. A. 1994. Estimating disease severity and incidence. Pages 117-147 in: Epidemiology and Management of Root Diseases. Springer Verlag, Berlin, Heidelberg.

Campbell, R. N., Schweers, V. H., and Hall, D. H. 1982. Corky root of tomato in California caused by Pyrenochaeta lycopersici and control by soil fumigation. Plant Dis. 66:657-661.

Carini, P., Marsden, P. J., Leff, J. W., Morgan, E. E., Strickland, M. S., and Fierer, N. 2016. Relic DNA is abundant in soil and obscures estimates of soil microbial diversity. Nat. Microbiol. 2:16242.

Cole, J. R., Wang, Q., Fish, J. A., Chai, B., McGarrell, D. M., Sun, Y., Brown, C. T., Porras-Alfaro, A., Kuske, C. R., and Tiedje, J. M. 2014. Ribosomal Database Project: Data and tools for high throughput rRNA analysis. Nucleic Acids Res. 42:D633-D642.

Derr, R. E. 2013. Ordinal Response Modeling with the LOGISTIC Procedure. Proceedings of the SAS Global Forum 2013 Conference, SAS Institute Inc., Cary, NC.

Díaz-Hernández, S., Gallo-Llobet, L., Domínguez-Correa, P., and Rodríguez, A. 2017. Effect of repeated cycles of soil solarization and biosolarization on corky root, weeds and fruit yield in screen-house tomatoes under subtropical climate conditions in the Canary Islands. Crop Prot. 94:20-27.

Dillard, H. R., and Cobb, A. C. 1998. Survival of Colletotrichum coccodes in infected tomato tissue and in soil. Plant Dis. 82:235-238.

Dixon, P. 2003. VEGAN, a package of R functions for community ecology. J. Veg. Sci. 14:927-930.

Ebihara, Y., and Uematsu, S. 2013. Survival of strawberry-pathogenic fungi Fusarium oxysporum f. sp. fragariae, Phytophthora cactorum and Verticillium dahliae under anaerobic conditions. J. Gen. Plant Pathol. 80: 50-58.

Hewavitharana, S. S., and Mazzola, M. 2016. Carbon source-dependent effects of anaerobic soil disinfestation on soil microbiome and suppression of Rhizoctonia solani AG-5 and Pratylenchus penetrans. Phytopathology 106: 1015-1028.

Hewavitharana, S. S., Ruddell, D., and Mazzola, M. 2014. Carbon sourcedependent antifungal and nematicidal volatiles derived during anaerobic soil disinfestation. Eur. J. Plant Pathol. 140:39-52.

Joint Genome Institute. 2016. BBTools. United States Department of Energy, Walnut Creek, CA. https://jgi.doe.gov/data-and-tools/bbtools/. 
Kabir, Z., Bhat, R. G., and Subbarao, K. V. 2004. Comparison of media for recovery of Verticillium dahliae from soil. Plant Dis. 88:49-55.

Katase, M., Kubo, C., Ushio, S., Ootsuka, E., Takeuchi, T., and Mizukubo, T. 2009. Nematicidal activity of volatile fatty acids generated from wheat bran in reductive soil disinfestation. Jpn. J. Nematol. 39:53-62.

Lamers, J. G., Runia, W. T., Molendijk, L. P. G., and Bleeker, P. O. 2010. Perspectives of anaerobic soil disinfestation. Acta Hortic. 883:277-283.

Last, F. T., and Ebben, M. H. 1966. The epidemiology of tomato brown root rot. Ann. Appl. Biol. 57:95-112.

Lauber, C. L., Zhou, N., Gordon, J. I., Knight, R., and Fierer, N. 2010. Effect of storage conditions on the assessment of bacterial community structure in soil and human-associated samples. FEMS Microbiol. Lett. 307:80-86.

Li, Y. F., Chen, P. H., and Yu, Z. 2014. Spatial and temporal variations of microbial community in a mixed plug-flow loop reactor fed with dairy manure. Microbial. Biotechnol. 7:332-346.

Lievens, B., Brouwer, M., Vanachter, A. C. R. C., Cammue, B. P. A., and Thomma, B. P. H. J. 2006. Real-time PCR for detection and quantification of fungal and oomycete tomato pathogens in plant and soil samples. Plant Sci. 171:155-165.

López-Pérez, J.-A., Le Strange, M., Kaloshian, I., and Ploeg, A. T. 2006. Differential response of $M i$ gene-resistant tomato rootstocks to root-knot nematodes (Meloidogyne incognita). Crop Prot. 25:382-388.

Louws, F. J., Rivard, C. L., and Kubota, C. 2010. Grafting fruiting vegetables to manage soilborne pathogens, foliar pathogens, arthropods and weeds. Sci. Hortic. (Amsterdam) 127:127-146.

Lupatini, M., Korthals, G. W., de Hollander, M., Janssens, T. K. S., and Kuramae, E. E. 2017. Soil microbiome is more heterogeneous in organic than in conventional farming system. Front. Microbiol. 7:2064.

McMurdie, P. J., and Holmes, S. 2013. phyloseq: An R package for reproducible interactive analysis and graphics of microbiome census data. PLoS One 8:e61217.

Meints, H., and Feil, H. 2017. Method of biological soil decontamination. European Patent 2352602.

Minuto, A., Gilardi, G., Gullino, M. L., and Garibaldi, A. 2008. Increasing severity of attacks of Colletotrichum coccodes on grafted tomatoes. Acta Hortic. 789:101-106.

Momma, N., Kobara, Y., Uematsu, S., Kita, N., and Shinmura, A. 2013. Development of biological soil disinfestations in Japan. Appl. Microbiol. Biotechnol. 97:3801-3809.

Momma, N., Momma, M., and Kobara, Y. 2010. Biological soil disinfestation using ethanol: effect on Fusarium oxysporum f. sp. lycopersici and soil microorganisms. J. Gen. Plant Pathol. 76:336-344.

Momma, N., Yamamoto, K., Simandi, P., and Shishido, M. 2006. Role of organic acids in the mechanisms of biological soil disinfestation (BSD). J. Gen. Plant Pathol. 72:247-252.

Mowlick, S., Inoue, T., Takehara, T., Kaku, N., Ueki, K., and Ueki, A. 2013a. Changes and recovery of soil bacterial communities influenced by biological soil disinfestation as compared with chloropicrin-treatment. AMB Express $3: 46$.

Mowlick, S., Inoue, T., Takehara, T., Tonouchi, A., Kaku, N., and Ueki, K. 2014. Usefulness of Japanese-radish residue in biological soil disinfestation to suppress spinach wilt disease accompanying with proliferation of soil bacteria in the Firmicutes. Crop Prot. 61:64-73.

Mowlick, S., Takehara, T., Kaku, N., Ueki, K., and Ueki, A. 2013b. Proliferation of diversified clostridial species during biological soil disinfestation incorporated with plant biomass under various conditions. Appl. Microbiol. Biotechnol. 97:8365-8379.

Paulson, J. N., Stine, O. C., Bravo, H. C., and Pop, M. 2013. Differential abundance analysis for microbial marker-gene surveys. Nat. Methods 10:1200-1202.

R Core Team. 2015. R: A language and environment for statistical computing. R Core Team. http://www.R-project.org/.

Rabenhorst, M. C. 2008. Protocol for using and interpreting IRIS tubes. Soil Surv. Horiz. 49:74-77.

Rabenhorst, M. C., and Burch, S. N. 2006. Synthetic iron oxides as an indicator of reduction in soils (IRIS). Soil Sci. Soc. Am. J. 70:1227-1236.
Rivard, C. L., O’Connell, S., Peet, M. M., and Louws, F. J. 2010. Grafting tomato with interspecific rootstock to manage diseases caused by Sclerotium rolfsii and southern root-knot nematode. Plant Dis. 94:1015-1021.

Rodriguez-Kabana, R., and King, P. S. 1980. Use of mixtures of urea and blackstrap molasses for control of root-knot nematodes in soils. Nematropica 10:38-44.

Rubin, B. E. R., Gibbons, S. M., Kennedy, S., Hampton-Marcell, J., Owens, S., and Gilbert, J. A. 2013. Investigating the impact of storage conditions on microbial community composition in soil samples. PLoS One 8:e70460.

Runia, W., Thoden, T., Molendijk, L., van den Berg, W., Termorshuizen, A., Streminska, M., van der Wurff, A., Feil, H., and Meints, H. 2014. Unravelling the mechanism of pathogen inactivation during anaerobic soil disinfestation. Pages 177-193 in: VIII International Symposium Chemical and NonChemical Soil and Substrate Disinfestation, Vol 1044, Torino, Italy.

Serrano-Pérez, P., Rosskopf, E., De Santiago, A., and Rodríguez-Molina, M. del C. 2017. Anaerobic soil disinfestation reduces survival and infectivity of Phytophthora nicotianae chlamydospores in pepper. Sci. Hortic. (Amsterdam) 215:38-48.

Shennan, C., Muramoto, J., Koike, S., Baird, G., Fennimore, S., Samtani, J., Bolda, M., Dara, S., Daugovish, O., Lazarovits, G., Butler, D., Rosskopf, E., Kokalis-Burelle, N., Klonsky, K., and Mazzola, M. 2018. Anaerobic soil disinfestation is an alternative to soil fumigation for control of some soilborne pathogens in strawberry production. Plant Pathol. 67:51-66.

Shennan, C., Muramoto, J., Lamers, J., Mazzola, M., Rosskopf, E. N., KokalisBurelle, N., Momma, N., Butler, D. M., and Kobara, Y. 2014. Anaerobic soil disinfestation for soil borne disease control in strawberry and vegetable systems: Current knowledge and future directions. Acta Hortic. 1044: $165-175$.

Shishkoff, N., and Campbell, R. N. 1990. Survival of Pyrenochaeta lycopersici and the influence of temperature and cultivar resistance on the development of corky root of tomato. Plant Dis. 74:889-894.

Shrestha, U., Dee, M. E., Ownley, B. H., and Butler, D. M. 2018. Anaerobic soil disinfestation reduces germination and affects colonization of Sclerotium rolfsii sclerotia. Phytopathology 108:342-351.

Strauss, S. L., and Kluepfel, D. A. 2015. Anaerobic soil disinfestation: A chemical-independent approach to pre-plant control of plant pathogens. J. Integr. Agric. 14:2309-2318.

Streminska, M. A., van der Wurff, A. W. G., Runia, W. T., Thoden, T. C., Termorshuizen, A. J., and Feil, H. 2014. Changes in bacterial and fungal abundance in the soil during the process of anaerobic soil disinfestation. Acta Hortic. 1041:95-102.

Ueki, A., Takehara, T., Ishioka, G., Kaku, N., and Ueki, K. 2017. Degradation of the fungal cell wall by clostridial strains isolated from soil subjected to biological soil disinfestation and biocontrol of Fusarium wilt disease of spinach. Appl. Microbiol. Biotechnol. 101:8267-8277.

van Agtmaal, M., van Os, G. J., Hol, W. H. G., Hundscheid, M. P. J., Runia, W. T., and Hordijk, C. A. 2015. Legacy effects of anaerobic soil disinfestation on soil bacterial community composition and production of pathogen-suppressing volatiles. Front. Microbiol. 6:701.

van Overbeek, L., Runia, W., Kastelein, P., and Molendijk, L. 2013. Anaerobic disinfestation of tare soils contaminated with Ralstonia solanacearum biovar 2 and Globodera pallida. Eur. J. Plant Pathol. 138:323-330.

Vawdrey, L. L., and Stirling, G. R. 1997. Control of root-knot nematode (Meloidogyne javanica) on tomato with molasses and other organic amendments. Australas. Plant Pathol. 26:179-187.

Vrisman, C. M., Testen, A. L., Elahi, F., and Miller, S. A. 2017. First report of tomato brown root rot complex caused by Colletotrichum coccodes and Pyrenochaeta lycopersici in Ohio. Plant Dis. 101:247.

Welbaum, G. E., Sturz, A. V., Dong, Z., and Nowak, J. 2004. Managing soil microorganisms to improve productivity of agro-ecosystems. Crit. Rev. Plant Sci. 23:175-193.

Wen, T., Huang, X., Zhang, J., and Cai, Z. 2015. Effects of biological soil disinfestation and water regime on suppressing Artemisia selengensis root rot pathogens. J. Soils Sediments 16:215-225. 